\title{
Influence of essential oils and organic acids blend on productive performance, immune status and controlling of Clostridium perferingens infections in broiler chickens
}

\author{
Tony, M. A. ${ }^{1}$, Samah H. Mohamed ${ }^{2}$, Ashgan F. El-Sissi ${ }^{2}$ and Hamoud \\ M. M. ${ }^{3}$ \\ 1) Department of Nutrition and Clinical Nutrition, Faculty of Veterinary \\ Medicine, Cairo University, Egypt 2) Department of Immunology, Animal \\ Health Research Institute, Dokki, Giza, Egypt. 3) Department of Poultry \\ Diseases, Faculty of Veterinary Medicine, Cairo University, Giza, Egypt.
}

\begin{abstract}
The present study was conducted to evaluate the effects of a commercial blend of cinnamaldehyde, thymol, eugenol combined with propionic, formic and sorbic acids (Fordex $®$ ) on zootechnical performance, immune status and controlling of Clostridium perferingens infections in broiler chickens. A total of 300 one-dayold chicks (Hubbard breed) were reared on floor pens and allocated randomly to three dietary treatments. The first group consumed basal broiler diets without any additive and served as a control group (G1). Broiler chicks in the second and third groups (G2 and G3) consumed diets containing Fordex ${ }^{\circledR}$ at 250 and 500 g/ton feed respectively. Feed and water were offered ad-libitum for 35 days experimental period. Feed consumption and body weight were recorded weekly to calculate body gain and feed conversion. Blood samples were collected weekly, after vaccination and after challenge from each group to evaluate the immune status and some immunological parameters. At day 16 of age 25 birds from each group were isolated and challenged orally with $1 \mathrm{ml}$ containing Clostridium perferingens $(107 \mathrm{cfu} / \mathrm{mL})$ daily for 3 consecutive days. Postchallenge, lesion scores, mortalities and intestinal Clostridium perferingenslevels were assessed. Feed intake and live body gain were improved significantly $(p<0.05)$. Feed conversion (FCR) was reduced in broiler chickens receiving Fordex ${ }^{\circledR}$ compared with the control group. The best results for live body weight and FCR were recorded in G3. The results of immunological parameters measured showed that additive used could enhance broiler chickens innate immunity as it significantly increased $(\mathrm{p}<0.05)$ phagocytic activity and humoral immune responses against vaccines. Fordex ${ }^{\circledR}$ reduced the lesion scores during infections. The $\log 10 \mathrm{C}$. perfringens/g of intestinal contents was significantly reduced $(\mathrm{p}<0.05)$ in the treated
\end{abstract}


groups. Birds in the third group showed the best results. Mortality was reduced in both treated groups in contrast to the control group.

\section{Introduction}

Since the early 1950's antibiotics have been widely used in poultry feeds, at first primarily to control diseases and recently to promote growth and improve feed conversion. Use of antibiotics has been banned or eliminated in many countries and legislative action to limit their use is probable in many others. Furthermore, withdrawal of antibiotics from poultryproducts created need for alternative solutions which would improve health and production traits of broiler chickens. Therefore, alternatives to antibiotics are of great interest in the poultry industry. Several authors have extensively reviewed and compared various compounds regarded as alternatives to antibiotics in animal production (Langhout, 2000; Mellor, 2000a,b; Wenk, 2000; Taylor, 2001; Tony et al, 2014).

Clostridium perfringensis a grampositive, anaerobic and sporeforming bacteria. The overgrowth of $C$. perfringensin the small intestine can result in necrotic enteritis (NE), an enteric disease that can cause significant economic losses in the poultry industry (Olkowski et al, 2008). Moreover, consuming poultry meat contaminated with these bacteria can cause human food poisoning (Warrell, 2003 and Van Immerseel et al, 2004). Collier et al, (2003) mentioned that the use of dietary antibiotics has been one of the primary measures to control $\mathrm{NE}$ in poultry production. The restricted use of dietary antibiotics has led to the prevalence of $\mathrm{NE}$ in poultry production, high economic losses and health hazard have been reported (McDevitt et al, 2006).

Phytogenic additives (phytobiotics) are substances derived from medicinal plants or spices which have positive effect on production and health of animals. Whole plants, parts of plants, plant extracts or essential oils can be used as phytobiotics. Phytogenic additives influence positively the consumption and conversion of feed, digestibility and gain of broiler chickens (Ertas et al, 2005). Essential oil is a mixture of fragrant, volatile compounds named after the aromatic characteristics of plant materials from which they are isolated. Essential oils are already marketed for use in animal production and are claimed to be "digestive enhancers" (Williams and Losa, 2001). Eugenol and cinnamaldehyde are two important terpenoids found in cinnamon, they have antibacterial activity (Chang et al, 2001) and antioxidant effect (Dragland et al, 2003; Lee and Shibamoto, 2002). Sadeghi (2012), reported that cinnamon and herbal mixtures significantly improved the 
immune response to the New Castle disease in broiler chickens.

Short-chain organic acids have also been added in animal feeds as antimicrobial agents (Cherrington, et al, 1991 and Dibner and Buttin, 2002). Because of their antimicrobial properties, organic acids are also viewed as alternatives to antibiotic growth promoters.

The modes of action of herbal extracts and/or organic acids available on the market are not well understood. Limitations are more apparent for compounds that are mixtures of several extracts or components, each with a different claimed activity.

The present study aimed at determining the live performance of broilers fed on corn-soybean meal all-vegetable diets supplemented with a commercial blend of cinnamaldehyde, thymol, eugenol combined with propionic, formic and sorbic acids (Fordex $\AA$ ) at 250 and $500 \mathrm{~g} /$ ton of feed. Body weight, feed intake, feed conversion, and the evaluation of immune status were measured in experimental broiler chickens raised to $35 \mathrm{~d}$. The effects of additive used were also evaluated the prevalence of Clostridium perferingensin broiler chickens.

\section{Materials and Methods \\ Fordex ${ }^{\circledR}$}

Fordex ${ }^{\circledR}$ is a commercial feed additive product containing mixtures of essential oils (cinnamaldehyde, thymol and eugenol) and blend of short chain organic acids (propionic, formic and sorbic acids). Fordex ${ }^{\circledR} \quad$ is manufactured by DexIbérica, S. A. - Animal nutrition experts, Spain. Experimental Birds and housing Three hundred 1-d-old chicks (Hubbard breed) of both sexes were obtained from a local hatchery. Chicks were weighed and randomly allocated into three dietary treatment groups on floor pen at the Poultry Rearing Centre, Department of Veterinary Hygiene and Management, Faculty of Veterinary Medicine, Cairo University, Egypt. Birds in all experimental groups were vaccinated against Newcastle Disease (ND), Infectious bronchitis (IB) and Gumboro (IBDV) diseases according the vaccination program showed in table (1).

\section{Diets and feeding program}

Corn-soybean meal all-vegetable basal diets were formulated to cover the nutrient requirements for Hubbard broilers (Hubbard manual catalogue 2002). Three stages diets (starter, grower and finisher) in the form of mash and water were provided ad-libitum during the 35 days experimental period (Table 2). Control (G1) birds were offered non-supplemented basal diets. Treatment groups 1 and 2 (G2 and G3) were fed diets containing Fordex® at 250 and $500 \mathrm{~g} /$ ton feed respectively. Feed and water were offered ad-libitum for 35 days experimental period. Feed consumption and body weight were 
recorded weekly to calculate body weight gain and feed conversion.

Blood samples and immunological parameters

- Heparinized blood were collected from all groups (5 samples/group) at 10 and 19 days of age and at 3 days post challenge with Clostridium perferingens for phagocytosis assay.

- Serum samples

samples/group) were collected at the same intervals for lysozyme and nitric oxide assay \& at weekly interval for detection of antibody titres against vaccination, and at the end of the experiment for detection of GSH and MDA.

\section{Evaluation of innate immunity} Assay of phagocytosis

The test was performed according to Bos and Souza, (2000) with some modification. Briefly, peripheral blood mononuclear cell layer was collected, washed and re-suspended in RPMI-1640 supplemented with $15 \%$ FCS. Then monolayer of macrophages was obtained by seeding $1 \mathrm{ml} 5 \times 10^{6}$ mononuclear cells in culture and staining chambers with cover slip and incubated for $1 \mathrm{hr}$ at $37^{\circ}$ in $5 \% \mathrm{co}_{2}$ and $99 \%$ humidity. Non adherent cells were removed by washing 3 times ,then after incubation for 24 hrs, the adherent macrophages were incubated at the same condition with $1 \mathrm{ml}$ Candida albicans $\left(10^{7} / \mathrm{ml}\right.$ RPMI with $15 \%$ FCS), washed 3 times, fixed and stained. Finally count 100 macrophages to determine percent of phagocytic macrophags (number of phagocytic macrophages/total number of macrophages) and phagocytic index (number of macrophages engulf $\geq 3$ Candida spores/total no of phagocytic macrophages.

\section{Lysozyme Assay}

Lysozyme activity was measured by agarose gel plate lyses assay according to Peeters and Vantrappen (1977). Lysoplates were prepared by dissolving $1 \%$ agarose in $0.06 \mathrm{mPBS}$ at $\mathrm{pH} 6.3$ in which Micrococcus lysodeikticus (50 mg/100 $\mathrm{ml}$ agarose) had been dispersed. Then $25 \mu$ of serum samples and standard lysozyme were added in each well. After 18 hours the cleared zones diameter were measured. The concentration of lysozyme was obtained from logarithmic curve prepared using standard lysozyme solution.

\section{Nitric oxide assay}

It carried out according to Yang et al (2010). 100 $\mu 1$ of serum sample was mixed with $80 \mu \mathrm{l}$ of $375 \mathrm{mM}$ $\mathrm{ZnSO} 4$ and $120 \mu \mathrm{l}$ of $275 \mathrm{Mm}$ $\mathrm{NaOH}$, then centrifuged at 13000 rpm for $20 \mathrm{~min}$ to remove proteins. Supernatant was obtained and added to $400 \mathrm{mg}$ of $\mathrm{Cu}$ plated $\mathrm{Cd}$, then shook for $2.5 \mathrm{~h}$ at room temperature after adding $100 \mu$ of 0.2 M glycine buffer. 100- $\mu 1$ Supernatant was added into 96-well ELISA plate then added $100 \mu$ of Griess reagent. The optical density was determined at $545 \mathrm{~nm}$ with an ELISA plate reader. Nitric oxide concentration was calculated from standard curve using NaNO2. 


\section{Evaluation of humeral immune} response

Antibody titres against Newcastle (NDV) using Haemagglutination inhibition test (HI) according to Beard (1989) were measured. Antibody titres against Gumboro disease (IBDV) using ELISA kit were detected according to the manufacturer's instructions (QIAGEN Leipzig $\mathrm{GmbH}$, Germany).

3. Detection of glutathione (GSH) and Malondialdehyde (MDA)

Glutathione was measured chemically according to Ellman et al (1959). MDA was detected according to Ohkawa (1979).

\section{Clostridium} challenge protocol

perferingens

The field isolate of $C$. Perfringens used in the challenging experiment was characterized before by PCR technique as a type $\mathrm{A}$ toxin producer (Mohamed et al., 2009). The organism was cultured anaerobically on Blood Agar Base (Becton, Dickinson and Co., Sparks, MD, USA) containing 5\% sheep blood for $18 \mathrm{~h}$ at $37^{\circ} \mathrm{C}$, then aseptically inoculated into cooked meat medium (Difco Labs, Detroit, MI, USA) and incubated anaerobically overnight at $37^{\circ} \mathrm{C}$. Twenty five birds from each group were examined at 15 days of age for C. Perfringens then orally challenged with gavage $(1 \mathrm{ml} /$ chick) on day 16,17 and 18 of the experiment with this actively growing culture of $C$. perfringens (McReynolds et al, 2009).

\section{Pathological examination}

Birds were observed on a basis at least once daily for any signs of NE and all birds that died during the course of experiments were necropzied to determine the cause of death. On day 28 , the surviving chickens were killed by cervical dislocation, weighed and necropzied immediately. Intestinal tracts were removed and intestinal lesions were scored according to the method of (Prescott et al, 1978).

Gross lesions associated with NE, the jejunum and ileum approximately $10 \mathrm{~cm}$ cranial and dorsal to Meckel's diverticulum was examined. Lesion scores were recorded using the following criteria: $0=$ no gross lesions, normal intestinal appearance; $1=$ thin-walled or friable, gray appearance; 2 = thin-walled, focal necrosis, gray appearance, small amounts of gas production; $3=$ thin walled, sizable patches of necrosis, gas-filled intestine, small flecks of blood; $4=$ severe extensive necrosis, marked haemorrhage, large amounts of gas in intestine.

\section{Enumeration of $C$. perfringens}

Intestinal sampling to determine the concentration of $C$. perfringensin intestinal contents was performed on days 15 (one day pre-challenge), 19 (one day post-challenge) and 25 (7 days post-challenge) of experiment. On each time, four chicks were randomly removed from each treatment then killed. Birds were killed by cervical dislocation, the abdominal cavity 
was opened and all digest contents of ileum were immediately collected under aseptic conditions into sterile plastic bags and put on ice, until they were transported to the laboratory for enumeration of microbial populations. About $4 \mathrm{~g}$ of the intestinal content was placed in $10 \mathrm{~mL}$ of anaerobic thioglycollate, vortex for $30 \mathrm{~s}$ and a $0.5 \mathrm{~mL}$ aliquot of intestinal digesta was removed and placed into $4.5 \mathrm{~mL}$ of thioglycollate medium. Ten-fold serial dilutions were performed, plated on reinforced clostridial agar and incubated $\left(24 \mathrm{~h}\right.$ at $\left.37^{\circ} \mathrm{C}\right)$. All of the $C$. perfringensculture work was performed in an anaerobic hood. Plates containing coloniesexhibiting typical morphology with more than 30 or less than 300 colonies were counted and recorded. Mortality was recorded daily.

\section{Statistical analysis}

All data were statistically analyzed using IBM SPSS $®$ version 19 software for personal computer (2010). Means were compared by one way ANOVA $(p<0.05)$ using Post Hoc, Duncan test according to Snedecor and Cochran (1980).

Table 1. Vaccination programme

\begin{tabular}{|c|c|c|}
\hline Age (days) & Vaccine* & Application \\
\hline 7 & Bivalent ND-Hitchner B1 and IB & Eye drops \\
\hline 14 & ND-Hitchner B1 & Eye drops \\
\hline 16 & Gumboro IBDV-D78 & Drinking water \\
\hline 21 & ND- Lasota & Drinking water \\
\hline 28 & Gumboro IBDV-D78 & Drinking water \\
\hline
\end{tabular}

*Vaccines were obtained from Intervet, Inc., Egypt

Table 2. Composition percentage and calculated nutrients profile of the basal diets

\begin{tabular}{|c|c|c|c|}
\hline Ingredients \% & $\begin{array}{c}\text { Starter } \\
(1-20 \text { day })\end{array}$ & $\begin{array}{c}\text { Grower } \\
(21-30 \text { day })\end{array}$ & $\begin{array}{c}\text { Finisher } \\
(31-35 \text { day })\end{array}$ \\
\hline Corn yellow & 51.7 & 56.15 & 61.15 \\
Corn gluten meal & 5.0 & 5.0 & 5.0 \\
Soybean meal (44\% CP) & 37.30 & 31.5 & 25.9 \\
Soy oil & 2.2 & 3.5 & 4 \\
Dicalcium phosphate & 1.6 & 1.6 & 1.7 \\
Limestone & 1.4 & 1.45 & 1.44 \\
Common salt & 0.4 & 0.4 & 0.4 \\
DL-Methionine & 0.05 & 0.05 & 0.06 \\
L-Lysin & 0.05 & 0.05 & 0.05 \\
Vitamin \& mineral premix* & 0.3 & 0.3 & 0.3 \\
\hline Calculated analysis: & 2951.8 & 3049.55 & 3124.07 \\
ME (Kcal/kg) & 23.2 & 21.29 & 19.00 \\
Crude Protein\% & 6 & 6.92 & 8 \\
Crude fat\% & 4.5 & 4.8 & 5.2 \\
Crude fibre\% & 1 & 1 & 1 \\
Calcium\% & 0.45 & 0.45 & 0.45 \\
Non-phytate phosphorus\% & & & \\
\hline
\end{tabular}

* Per kg premix: 1200000 IU vit. A, 350000 IU vit.D3, 4000 mg vit.E, 250 mg vit.B1, $800 \mathrm{mg}$ vit.B2, $600 \mathrm{mg}$ vit.B6, $3.2 \mathrm{mg}$ vit.B12, $450 \mathrm{mg}$ vit. K3, $4.5 \mathrm{~g}$ nicotinic acid, $1.5 \mathrm{~g}$ Ca-pantothenate, $120 \mathrm{mg}$ folic acid, $5 \mathrm{mg}$ biotin, $55 \mathrm{~g}$ choline chloride, $3 \mathrm{~g} \mathrm{Fe}, 2 \mathrm{~g} \mathrm{Cu}, 10 \mathrm{~g}$ Mn, 8 g Zn, 120 mg I, 40 mg Co. 
Results and discussion

Productive performance

The effects of different levels of Fordex $^{\circledR}$ feed additive on zootechnical performance of broiler chickens are shown in Table 3. Body weight and feed consumption of broilers fed on diets containing $500 \mathrm{~g} / \mathrm{Ton}$ of feed significantly improved $(p<0.05)$. The groups consumed diets containing additives by low dose of Fordex ${ }^{\circledR} 250 \mathrm{~g} /$ Ton of feed had higher body weight compared with the control group but differences were nonsignificant. The best feed conversion was observed in G3 group compared with $\mathrm{G} 1$ and $\mathrm{G} 2$ groups.

Improvement in body weight supported an earlier hypothesis suggesting that the herbal additives are valued for their beneficial effect on digestion, absorption and utilization of nutrients (Grieve, 1981 and Chopra et al, 1992). Furthermore, phytogenic feed additives are often claimed to improve the flavor and palatability of feed, thus enhancing productive performance (Jugl-Chizzola et al, 2006; Schoene et al, 2006).

Besides efficacy, application of phytogenic feed additives to livestock also has to be safe to the animal, the user, the consumer of the animal products and they are environment friendly. With respect to consumer safety, there is no hazard or undesired residues in animal or poultry products derived from animals fed those natural phytogenic feed. However, metabolic activity (e.g., absorption, potential to accumulate in edible tissues) differs widely among phytogenic compounds, and thus safety needs to be assessed separately for each individual phytogenic feed additive (Baba et al, 2005). Microbiologically, capsicum and cinnamon had powerful antimicrobial and antifungal activities against certain microorganisms known to be pathogenic to broiler chickens, particularly, Clostridium Spp., Salmonella Spp., E. coli, Staphylococcus aureusand Streptococcus spp. Which will synergistically reflected positively on broiler chickens productive performance (Kaushik et al, 2003; Mimica-Dukic et al, 2003; Chang et al, 2001).

Cinnamaldehyde content, eugenol and carvacrol contents (compounds identified in cinnamon) have shown strong antioxidant and antimicrobial activity (Tabak et al, 1999; Matovc and Lavadinovic, 1999; Lidia Dorantes et al, 2000). Organic acids are also viewed as alternatives to antibiotic growth promoters due to their antimicrobial properties. Therefore, cinnamon antimicrobial substances in combination with short chain organic acids may act as growth promoter which in turn inhibit intestinal pathogenic organisms and reflected on improving digestion and absorption. 
Immunological parameters

The results of the effects of Fordex ${ }^{\circledR}$ on innate immune response following vaccination were tabulated in Table 4. Chicken fed high dose of Fordex® supplement (G3) showed a significant increase in phagocytic percent and index following NDV and IBDV vaccinations compared with the control group (G1).

The obtained results may be due to the immunostimulatory effect of thymol ,cinnamaldehyde and eugenol. These results coincide with Faix et al (2009) who recorded a significant increase in phagocytic activity in broiler chickens fed a diet containing essential oil of cinnamon (cinnamaldehyde and eugenol). In the same regard Khaksar et al (2012) found that addition of Thyme essential oil in broilers fed wheat-based diet improved the immunity in terms of heterophil to lymphocyte ratio. Yakhkeshi et al (2011) reported that utilization of organic acid in broiler diet could stimulate the immune responses.

Lysozyme is natural defense mechanism. Its action is based on disintegrating the polysaccharide peptide complex of the cell wall of Gram-positive bacteria (Masschalck and Michiels, 2003). The value of lysozyme (Table 4) showed significant increase $(\mathrm{p}<0.05)$ in group 3 compared with control group. The increase of lysozyme may be subsequent to increase of lactobacillus bacteria caused by lowering $\mathrm{pH}$ with the additives used Khaksar et al (2012). In this regard Gudev et al (2004) showed that pigs fed phytogenic feed additive had a higher lysozyme amount in their serum.

Birds of G2 and G3 revealed significant decrease in Nitric Oxide (NO) levels compared with control group at $3^{\text {rd }}$ day post vaccination. The decrease in nitric oxide may be due to suppress growth of pathogenic bacteria by antibacterial effects of Fordex® (essential oils and organic acids blends) (Garcia et al, 2007 and Ozek et al, 2011). Pathogenic bacteria stimulate secretion of NO by their own LPS that continuously shad from their surface during their replication or death (Jakob et al, 1997).

The obtained data of humoral immune response (Figures 1 and 2) showed that the addition of high dose of Fordex ${ }^{\circledR}$ (G3) significant increase the antibody titers against NDV vaccines represented by $\log 2$ and numerically increased the antibody production against IBDV. The improvement of humoral immune response are mainly due to the immunostimulatory effect of Fordex ${ }^{\circledR}$ constituents .These results are in agreement with the findings of Khaligh et al (2011) and Sadeghi et al (2012) who studied the effects of blends of medicinal plants include cinnamon, thymol and others on humoral immunity of broiler chickens and found an increase in antibody titers against 
NDV. Ozek et al (2011) and Kazempour and Jahanian (2011) reported numerical increase on antibody titers against NDV and IBDV following dietary supplementation of organic acids in laying hens. Dehghani and Jahanian (2012) found significant increase in Newcastle disease, Gumboro and bronchitis disease virus antibodies in broilers fed on herbal and/or organic acids.

Table (5) shows the effect of Fordex ${ }^{\circledR}$ on serum malondialdehyde (MDA) and glutathione (GSH). The MDA activity was significantly lower in group supplemented with Fordex® at high doses (G3). In addition, GSH was significantly elevated in the same treated group in comparison with the control one. Lipid peroxidation is an autocatalytic mechanism leading to oxidative destruction of cellular membranes (Cheeseman, 1993). MDA is the main final product of lipid peroxidation and has been often used for determining oxidative damage (Sevanian and Mcleod, 1997).

The obtained results in the present study may be due to the antioxidant property of cinnamon and thymol oils, mainly due to the presence of phenolic $\mathrm{OH}$ groups which act as hydrogen donors to the peroxy radicals produced during the first step in lipid oxidation, thus retarding the hydroxy peroxide formation (Farag et al, 1989). Lin et al (2003) found that cinnamon oil

(1000 ppm) reduced MDA level, increased GSH and CAT activities. Hoffman-Pennesi and C. Wu (2010) showed that supplementing feed with antioxidants such as thymol and thyme oil raised the antioxidant capacity in the serum of broiler chickens. Amir Lin et al (2003) showed that essential oil of oregano potentially can exert antioxidant property in broiler chickens.

Clostridium

challenge

The impacts of Fordex ${ }^{\circledR}$ supplementation by the two doses on the lesion score, mortality and number of Clostridium perferingensin in broiler chicks are shown in Table 6.

All challenged birds in G1, G2 and G3 were observed dull, depressed and had abnormally wet droppings for the first 3-5 days after challenge. The intestinal gross lesions in most of the birds were conclusive of necrotic enteritis (NE), dilated small intestine with mucoid to roughened mucosa. Some birds showed liver infarctions. Overall the intestinal lesions of NE were reported in 10 birds (40\%) in treated group (G2) in comparison to $18(72 \%)$ in the control group. Only 5 (20\%) birds in G3 showed the symptoms of NE. Moreover, the data from the experiment showed that Fordex $^{\circledR}$ treated groups were efficacious and significantly reducing the severity of NE lesion scores $(p<0.05)$. The mean lesion scores recorded in G1 3.5 versus 2 and 1.8 in G2 and G3 respectively (Table 6). Mortality 
percent recorded $48 \%$ in G1 during the course of infection. Meanwhile it is 28 and $16 \%$ in G2 and G3 respectively. $C$. perfringens were enumerated in the ileum of the birds on day one and seventh post challenge and the base line $C$. perfringens count determined at one day pre-challenge (day 16 of experiment). The results indicated that the $\log 10 \mathrm{C}$. perfringens/g of intestinal contents was significantly reduced in the Fordex ${ }^{\circledR}$ treated groups with a $\log 10$ value of 3.6 and 2.1 at the $1^{\text {st }} \mathrm{d}$. post challenge in G2 and G3 respectively compared with 5.7 in the control group. $\log 10 \mathrm{cfu} / \mathrm{g}$ of $C$. perfringens $\left(7^{\text {th }} \mathrm{d}\right.$. post challenge) showed the same results and reduced significantly in the Fordex ${ }^{\circledR}$ treated groups. The best results of $C$. perfringens reduction were recorded in G3.

The current study demonstrated the beneficial effect of the Fordex ${ }^{\circledR}$ which revealed its supplementation favoured the reduction of $\mathrm{NE}$ lesions, mortality and number of $C$. perfringensin the gut of broiler chickens. The mode of action by which Fordex $^{\circledR}$ interacts with Clostridia to lower counts is not fully clear, but may be due to: 1) Eugenol and cinnamaldehyde are two important terpenoids have antibacterial activity (Chang $\boldsymbol{e t}$ al, 2001) and antioxidant effect (Dragland et al, 2003; Lee and Shibamoto, 2002). 2) Short-chain organic acids have also been added in animal feeds as antimicrobial agents Cherrington, et al (1991) and Dibner and Buttin, (2002). Their antimicrobial properties are accentuated at low $\mathrm{pH}$, where their dissociated carboxyl groups penetrate the microbial cells and lead to their eventual death Cherrington, et al (1991) and Roth (2000). Blends of organic acids having different $\mathrm{pKa}$ values have a broader spectrum of action throughout the intestine, where different $\mathrm{pH}$ values are encountered when the feed moves toward the large intestine. Organic acids also have energy values that may represent an immediate supply to the enterocytes (Eidelsburguer, 2001). Because of their antimicrobial properties, organic acids are also viewed as alternatives to antibiotic growth promoters. Their supplementation in broiler feeds, however, has shown conflicting results, in part because of the different organic acids, doses, microbial challenges, or evaluated responses that have been used in the published experiments (RafaczLivingston et al, 2005).

Innate immune response following challenged of Closterdium perfringens illustrated in Table 7 . Enhancement of innate immunity by Closterdium perfringens manifested by increase in phagocytic activity Figure 3. and it's killing molecules (nitric oxide and lysozyme) in all groups as immunological response of the body towards infection. These immunological responses were 
significant increase $(\mathrm{p}<0.05)$ in compared with control group. The best results of innate immune responses following Clostridium perfringens infection were recorded in G3.

In the same regard Zhou et al 2013 mention that both cell-mediated and antibody-mediated immune responses via MHC class I and II systems were actively involved in the host defense against $C$. perfringens infection in broilers. In vitro study Sumners et al., (2012) mention that Gene expression analysis of immune transcripts revealed significantly elevated expression of interferon (IFN)- $\gamma$, interleukin, inducible nitric oxide synthase (iNOS) in regards to $C$. perfringens toxins exposure.

In conclusion, using blend of cinnamaldehyde, thymol, eugenol combined with propionic, formic and sorbic acids (Fordex®) as feed additives reflected positively on the productive performance of broiler chickens. Fordex ${ }^{\circledR}$ feed additive could enhance the immune status and reduces the prevalence and infections by Clostridium perferingens.

Table 3. Performance parameters measured (day 35) (Mean $\pm S D)$

\begin{tabular}{|c|c|c|c|}
\hline Parameter & $\begin{array}{c}\text { G1 } \\
\text { Control group } \\
\end{array}$ & $\begin{array}{c}\text { G2 }\left(\text { Fordex }^{(B)}\right) \\
250 \text { g/Ton of feed }\end{array}$ & $\begin{array}{c}\text { G3 }\left(\text { Fordex }{ }^{\circledR}\right) \\
500 \text { g/Ton of feed }\end{array}$ \\
\hline Body & $2000.0 \pm 22.1^{\mathrm{a}}$ & $2015.7 \pm 18.2^{\mathrm{a}}$ & $2110.2 \pm 25.2^{b}$ \\
\hline Body we & $1960.0 \pm 15.3^{\mathrm{a}}$ & $1975.7 \pm 19.1^{\mathrm{a}}$ & $2070.2 \pm 20.5^{b}$ \\
\hline Feed Intake (g/bird) & $3292.5 \pm 45.2^{\mathrm{a}}$ & $3310.5 \pm 35.5^{\mathrm{a}}$ & $3457.5 \pm 46.7^{\mathrm{b}}$ \\
\hline FCR & 1.68 & 1.68 & 1.67 \\
\hline
\end{tabular}

Figures in the same row with different letters are statistically significantly different $(p<0.05)$.

Table 4. Effects of Fordex® on phagocytic activity, serum lysozyme and Nitric Oxide (NO) following vaccination (Mean $\pm S D$ )

\begin{tabular}{|c|c|c|c|}
\hline Parameter & $\begin{array}{c}\text { G1 } \\
\text { Control group }\end{array}$ & $\begin{array}{c}\text { G2 }\left(\text { Fordex }{ }^{\circledR}\right) \\
250 \text { g/Ton of feed }\end{array}$ & $\begin{array}{c}\text { G3 }\left(\text { Fordex }^{\circledR}\right) \\
500 \text { g/Ton of feed }\end{array}$ \\
\hline $\begin{array}{l}\text { Phagocytic percent } \\
3^{\text {rd }} d \text { post NDV vaccine } \\
3^{\text {rd }} d \text { post IBDV vaccine }\end{array}$ & $\begin{array}{l}53 \pm 1.84^{\mathrm{a}} \\
54 \pm 2.21^{\mathrm{a}}\end{array}$ & $\begin{array}{l}55 \pm 2.84^{\mathrm{a}} \\
57 \pm 3.25^{\mathrm{a}}\end{array}$ & $\begin{array}{l}64 \pm 1.49^{\mathrm{b}} \\
59 \pm 1.49^{\mathrm{b}}\end{array}$ \\
\hline $\begin{array}{c}\text { Phagocytic index } \\
3^{\text {rd }} \text { post NDV vaccine } \\
3^{\text {rd }} d \text { post IBDV vaccine }\end{array}$ & $\begin{array}{l}0.37 \pm 0.02^{\mathrm{a}} \\
0.39 \pm 0.06^{\mathrm{a}}\end{array}$ & $\begin{array}{l}0.41 \pm 0.04^{\mathrm{a}} \\
0.43 \pm 0.02^{\mathrm{a}}\end{array}$ & $\begin{array}{l}0.55 \pm 0.02^{b} \\
0.54 \pm 0.02^{b}\end{array}$ \\
\hline $\begin{array}{c}\text { Lysozyme } \\
3^{\text {rd }} d \text { post NDV vaccine } \\
3^{\text {rd }} d \text { post IBDV vaccine }\end{array}$ & $\begin{array}{l}21.4 \pm 1.5^{\mathrm{a}} \\
22.0 \pm 1.6^{\mathrm{a}}\end{array}$ & $\begin{array}{l}21.50 \pm 1.5^{\mathrm{a}} \\
22.19 \pm 1.7^{\mathrm{a}}\end{array}$ & $\begin{array}{l}22.13 \pm 1.35^{\mathrm{a}} \\
23.13 \pm 139^{\mathrm{b}}\end{array}$ \\
\hline $\begin{array}{c}\text { Nitric Oxide (NO) } \\
3^{\text {rd }} \text { d post NDV vaccine } \\
3^{\text {rd }} \text { d post IBDV vaccine }\end{array}$ & $\begin{array}{l}25.82 \pm 0.83^{\mathrm{a}} \\
24.25 \pm 1.38^{\mathrm{a}}\end{array}$ & $\begin{array}{l}14.62 \pm 0.55^{\mathrm{b}} \\
18.50 \pm 1.19^{\mathrm{b}}\end{array}$ & $\begin{array}{l}14.04 \pm 0.67^{b} \\
17.88 \pm 0.69^{b}\end{array}$ \\
\hline
\end{tabular}

Figures in the same row with different letters are statistically significantly different $(p<0.05)$. 


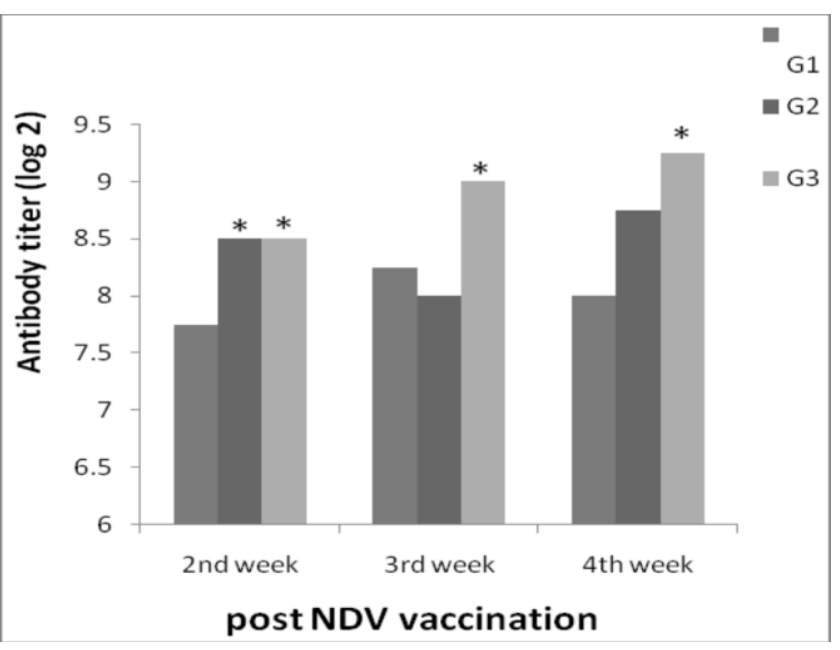

Figure 1. Effect of dietary supplementation of Fordex $® \quad$ on antibody titers against NDV vaccines

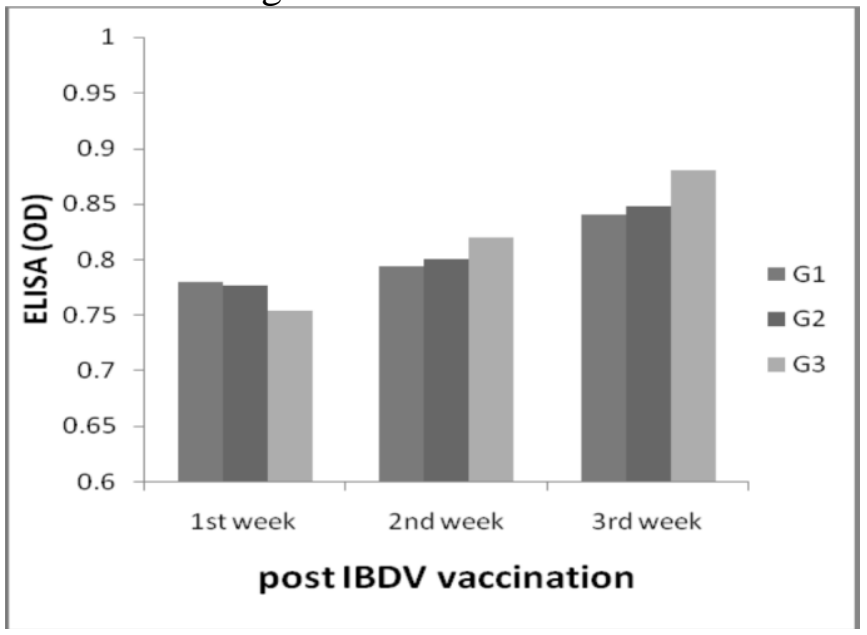

Figure 2. Effect of dietary supplementation of Fordex® on ELISA (OD) post IBDV vaccines

Table 5. Effects of Fordex ${ }^{\circledR}$ on serum glutathione (GSH) and malondialdehyde (MDA) at the end of the experimental period (Mean $\pm S D)$

\begin{tabular}{|c|c|c|c|}
\hline Parameter & $\begin{array}{c}\text { G1 } \\
\text { Control } \\
\text { group }\end{array}$ & $\begin{array}{c}\text { G2 } \text { (Fordex }^{\circledR} \text { ) } \\
\mathbf{2 5 0} \text { g/Ton of } \\
\text { feed }\end{array}$ & $\begin{array}{c}\text { G3 } \text { (Fordex }^{\circledR} \text { ) } \\
\mathbf{5 0 0} \text { g/Ton of } \\
\text { feed }\end{array}$ \\
\hline glutathione (GSH) & $3.31 \pm 0.11^{\mathrm{a}}$ & $3.73 \pm 0.04^{\mathrm{a}}$ & $4.37 \pm 0.10^{\mathrm{b}}$ \\
\hline $\begin{array}{c}\text { malondialdehyd } \\
\text { (MDA) }\end{array}$ & $11.62 \pm 0.16^{\mathrm{a}}$ & $10.95 \pm 0.08^{\mathrm{a}}$ & $9.55 \pm 0.20^{\mathrm{b}}$ \\
\hline
\end{tabular}

Figures in the same row with different letters are statistically significantly different $(p<0.05)$. 
Table 6. Effects of Fordex ${ }^{\circledR}$ on the lesion score, mortality and number of Clostridium perferingensin digesta following infection (Mean $\pm S D)$

\begin{tabular}{|c|c|c|c|}
\hline Parameter & $\begin{array}{c}\text { G1 } \\
\text { Control } \\
\text { group }\end{array}$ & $\begin{array}{l}\left.\text { G2 } \text { Fordex }^{(}\right) \\
250 \text { g/Ton of } \\
\text { feed }\end{array}$ & $\begin{array}{c}\text { G3 }\left(\text { Fordex }^{\circledR}\right) \\
500 \text { g/Ton of } \\
\text { feed }\end{array}$ \\
\hline Intestinal lesions & $18 / 25$ & $10 / 25$ & $5 / 25$ \\
\hline Lesion score & $3.5 \pm 0.19^{\mathrm{a}}$ & $2.0 \pm 0.15^{b}$ & $1.8 \pm 0.11^{\mathrm{c}}$ \\
\hline Mortality & $12 / 25$ & $7 / 25$ & $4 / 25$ \\
\hline Mortality \% & 48 & 28 & 16 \\
\hline $\begin{array}{c}\text { Log } 10 \mathrm{cfu} / \mathrm{g}\left(1^{\text {st }} \mathrm{d} \text {. post }\right. \\
\text { challenge })\end{array}$ & $5.7 \pm 0.2^{\mathrm{a}}$ & $3.6 \pm 0.8^{\mathrm{b}}$ & $2.1 \pm 0.9^{c}$ \\
\hline $\begin{array}{c}\text { Log } 10 \mathrm{cfu} / \mathrm{g} \\
\left(7^{\text {th }} \text { d. post challenge }\right)\end{array}$ & $6.2 \pm 0.5^{\mathrm{a}}$ & $3.8 \pm 0.7^{b}$ & $2.5 \pm 0.6^{\mathrm{c}}$ \\
\hline
\end{tabular}

Figures in the same row with different letters are statistically significantly different $(p<0.05)$.

Table 7. parameters of innate immune responses following Clostridium perfringensinfection (Mean $\pm S D$ )

\begin{tabular}{|c|c|c|c|}
\hline Parameter & $\begin{array}{c}\text { G1 } \\
\text { Control } \\
\text { group }\end{array}$ & $\begin{array}{c}\text { G2 } \text { (Fordex }^{\circledR} \text { ) } \\
\text { 250 g/Ton of } \\
\text { feed }\end{array}$ & $\begin{array}{c}\text { G3 } \text { (Fordex }^{\circledR} \text { ) } \\
\text { 500 g/Ton of } \\
\text { feed }\end{array}$ \\
\hline $\begin{array}{c}\text { Phagocytic } \\
\text { percent }\end{array}$ & $67 \pm 1.47^{\mathrm{a}}$ & $68 \pm 3.40^{\mathrm{a}}$ & $76 \pm 2.02^{\mathrm{b}}$ \\
\hline Phagocytic index & $0.51 \pm 0.004^{\mathrm{a}}$ & $0.60 \pm 0.03^{\mathrm{a}}$ & $0.67 \pm 0.02^{\mathrm{b}}$ \\
\hline Lysozyme & $44.49 \pm 4.29^{\mathrm{a}}$ & $45.05 \pm 3.36^{\mathrm{a}}$ & $62.64 \pm 3.13^{\mathrm{b}}$ \\
\hline Nitric Oxide & $29.03 \pm .92^{\mathrm{a}}$ & $32.43 \pm 1.63^{\mathrm{b}}$ & $32.99 \pm 2.35^{\mathrm{b}}$ \\
\hline
\end{tabular}

Figures in the same row with different letters are statistically significantly different $(p<0.05)$.

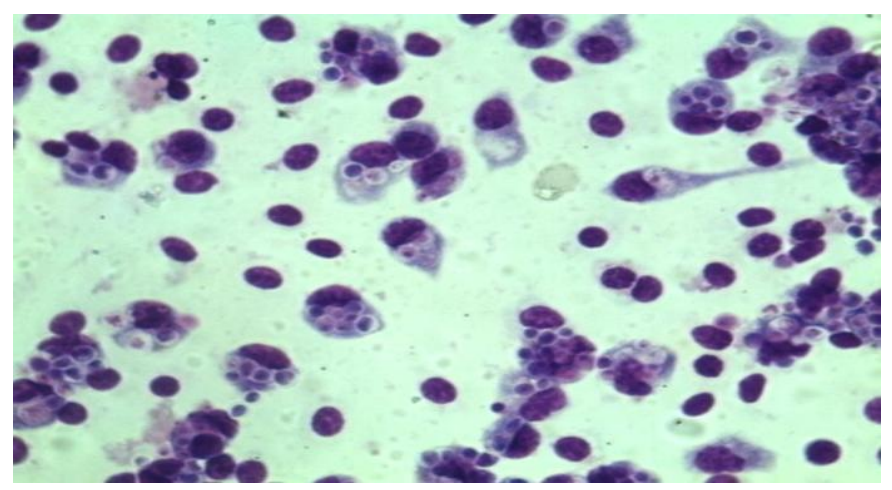

Figure 3. Peripheral blood mononuclear cells engulfing Candida spores 3 days post challenge with $C$. perfringens. Giemsa stain (X100). 
References

Baba, S., Osakabe, N., Natsume, M., Yasuda, A., Muto, Y., Hiyoshi, K., Takano, H., Yoshikawa, T. and Terao, J. (2005): Absorption, metabolism, degradation and urinary excretion of rosmarinic acid after intake of Perilla frutescens extract in humans. Eur. J. Nutr., 44: 1 - 9.

Beard, C.W., (1989): Serological procedures. In: Laboratory manual for the isolation and identification of avian pathogens published by the American Association of avian pathologists, 3rd ED., pp: 192-200.

Bos, H. and W. De Souza (2000): Phagocytosis of yeast: a method for concurrent quantification of binding and internalization using differential interference contrast microscopy. Journal of Immunological Methods,238:29-43.

Chang, S. T., Chen, P.F. and Chang, S.C. (2001): Antibacterial activity of leaf essential oils and their constituents from Cinnamomumosmophloeum. J. of Ethnopharmacology, 77: 123 - 127. Cheeseman KH (1993): Mechanism and effects of lipid peroxidation. Mol Aspects Med 14: 191-197.

Cherrington, C. A., M. Hinton, and I. Chopra. (1991): Organic acids: chemistry, antibacterial activity and practical applications. Adv. Microb. Physiol. 32:87-108.

Chopra, R., Nayar, S. and Chopra, I. (1992): Effect of dietary levels of spearmint (Mentha spicata) on broiler chicks performance. Puplications and information Directorate, New Delhi, India, pp. 414.

Collier, C. T., J. D. van der Klis, B. Deplancke, D. B. Anderson, and H. R. Gaskins. (2003): Effects of tylosin on bacterial mucolysis, Clostridium perfringens colonization, and intestinal barrier function in a chick model of necrotic enteritis. Antimicrob. Agents Chemother. 47:3311-3317.

Dehghani, N; R. Jahanian (2012): Effects of dietary organic acid supplementation on immune responses and some blood parameters of broilers fed diets with different protein levels. World's Poultry Science Journal 111-119.

Dibner, J. J., and P. Buttin. (2002): Use of organic acids as a model to study the impact of gut microflora on nutrition and metabolism. J. Appl. Poult. Res. 11:453-463.

Dragland S, Senoo H, Wake K, Holte K, Blomhoff $R$ (2003): Several culinary and medicinal herbs are importantsources of dietary antioxidants. J. Nutr 133: 1286-1290.

Eidelsburguer, U. (2001): Pages 107-121 in Recent Developments in Pig Nutrition 3. P. C. Garnsworthy and J. Wiseman, ed. Nottingham Univ. Press, Nottingham, UK.

Ellman ,GL, (1959): Tissue sulfdryl groups. Arch Biochem.Biophys, 82:70-77. 
Ellman GL (1958): Tissue sulfhydryl groups. Arch Biochem Biophys 81: 51-59.

Ertas, O.N., Guelert, T., Çiftci, M., Dalkilic, B., Simsek, U.G. (2005): Organic water additive on growth

performances, hematological parameters and cost effectiveness in broiler production. International J. of Poultry Science, 4: 879 - 884.

Faix ড̌, Faixová Z, Plachá I, Koppel J. (2009): Effect of cinnamomum zeylanicum essential oil on antioxidative status in broiler chickens. ActaVeterinaria Brno; 78:411-417.

Farag RS, Badei AZMA, Hewedi FM, El- Baroty GSA (1989): Antioxidant activity of some spice essential oils on linoleic acid oxidation in aqueous media. J. Am. Oil Chem. Soc., 66: 792-799.

Garcia V, Catala-Gregori $P$, Hernandez F,Megias MD and Madrid J. (2007). Effect of Formic Acid and Plant Extracts on Growth, Nutrient Digestibility, Intestine Mucosa Morphology,and Meat Yield of Broilers. J. Appl. Poult. Res.; 16: 555 - 62.

Grieve, M. (1981): A Modern Herbal. Penguin, UK, pp. 902.

Gudev D, Popova- Ralcheva S, Moneva1P, Bonovska M, Valchev G and Valcheva A.(2004): Effect of supplemental Sangrovit on some biochemical indices and leukocytes phagocytic activity in growing pigs. Arch. Zootec.; 7: 123 - 34.

Hoffman-Pennesi D. and C. Wu (2010): The effect of thymol and thyme oil feed supplementation on growth performance, serum antioxidant levels, and cecal Salmonella population in broilers. J. Appl. Poult. Res. 19 :432-443. Jacob, A. L., Goldberg, P. K., Bloom, N., Degenshein, G. A., and Kozinn, P. J. (1997): Endotoxin and bacteria in portal blood. Gastroenterology 72, 1268-1270.

Jugl-Chizzola, M., Ungerhofer, E., Gabler, C., Hagmuller, W., Chizzola, R., Zitterl-Eglseer, K. and Franz C. (2006): Thyme in the rearing of piglets. Munch. Tierarztl. Wochenschr., 119: 238 - 243.

Kaushik, R., Garg, G., Sharma, G. and Arora, C. (2003): Antibacterial activity of plant extracts from Uttaranchal Hills, India. Allelopathy J., 12: 205 - 213. Kazempour, F. and Jahanian R. (2011): Effect of different supplemental organic acids on immunocompetence and some blood metabolites in laying hens fed varying nonphytate phosphorus levels. $18^{\text {th }}$ European Symposium on Poultry Nutrition, Izmir, turkey, pp. 665-667.

Khaksar, V.Abolghasem Golian and Hassan KermanshahLee KW, Everts H, Kappert ,HJ (2012): Immune response and ilealmicroflora in broilers fed wheat-based diet with or without enzyme Endofeed W and supplementation of thyme essential oil or probiotic PrimaLac ${ }^{\circledR}$.African Journal of Biotechnology Vol. 11 (81), pp. 14716-14723. 
Khaligh, F, GhorbanaliSadeghi, Ahmad Karimi and AsaadVaziry(2011): Evaluation of different medicinal plants blends in diets for broiler chickens. Journal of Medicinal Plants Research Vol. 5 (10), pp. 1971-1977

Langhout, P. (2000): New additives for broiler chickens. World poultry, 16: 22-27.

Lee K.G. and Shibamoto T (2002): Determination of antioxidant potential of volatile extracts isolated from various herbs and spices. J Agr Food Chem 50: 4947-4952

Lidia Dorantes, Colmenero, R., Hernandez, H., Mota, L., Jaramillo, M.E., Fernandez, E. and Solano, C. (2000): Inhibition of growth of some foodborne pathogenic bacteria by Capsicum annum extracts. International J. of Food Microbiology, 57: 125-128.

Lin CC, Wu SJ, Chang CH, Nu LT (2003): Antioxidant activity of Cinnamomum cassia. Phytoth Res 17: 726-730

Masschalck, B. And Michiels, C.W. (2003): Antimicrobial properties of lysozyme in relation to foodborne vegetative bacteria. Microbiol. Rev. Crit., Vol. 29, No. 3, pp. 191-214

Matovc, M. and Lavadinovic, V. (1999): Essential oil composition of Mentha longifolia (L.) Huds. J. Essential Oil Bearing plants, 2: 78 81.

McDevitt, R. M., J. D. Brooker, T. Acamovic, and N. H. C. Sparks. (2006). Necrotic enteritis: A continuing challenge for the poultry industry. World's Poult. Sci. J. 62:221-247.

Mellor S. (2000a): Antibiotics are not the only growth promoters. World Poult., 16 (No 1): 14-15.

Mellor, S., (2000b):

Nutraceuticals-alternatives to antibiotics. World Poult., 16 (No 2): 30-33.

Mimica-Dukic, N., Bozin, B., Sokoviae, M., Mihajloviae, B. and Matavulj, M. (2003): Essential oils in nutrition. Plant Medicine, 69: 413 $-419$.

Mohamed, M.A., O.A. Sylvia and T.Y. Abdel Motelib, (2009): Essential oils in broiler nutrition. Assiut Vet. Med. J., 55: 255-275.

McReynolds, J., C. Waneck, J. Byrd, K. Genovese, S. Duke and D. Nisbet, (2009): Efficacy of multistrain direct-fed microbial and phytogenetic products in reducing necrotic enteritis in commercial broilers. Poult. Sci., 88: 20752080.

Ohkawa, H.; N. Ohishi and K.Yagi (1979): Assay for lipid peroxides in animals tissues by thiobarbituric acid reaction. Anal Biochem, 95:351-358.

Olkowski, A. A., C. Wojnarowicz, M. Chirino-Trejo, B. Laarveld, and G. Sawicki, (2008): Subclinical necrotic enteritis in broiler chickens: Novel etiological consideration based on ultrastructural and molecular changes in the intestinal tissue. Res. Vet. Sci. 85:543-553.

Ozek1, K., K.T. Wellmann, B. Ertekin and B. Tarım (2011): 
Effects of dietary herbal essential oil mixture and organic acid preparation on laying traits, gastrointestinal tract characteristics, blood parameters and immune response of laying hens in a hot summer season. Journal of Animal and Feed Sciences, 20, 575-586.

Peeters T. L. and G.R.Vantrappen (1977): Factors influencing lysozyme determination by lysoplate method. Cli. Chim. Acta ,74:217-255.

Prescott, J.F., R. Sivendra and D.A. Barnum, (1978): The use of bacitracin in the prevention and treatment of experimentallyinduced necrotic enteritis in the chicken.Can. Vet. J., 19: 181-183.

Rafacz-Livingston, K. A., C. Martinez-Amezcua, C. M. Parsons, D. H. Baker, and J. Snow. (2005): Citric acid improves phytate phosphorus utilization in cross breed commercial broiler chicks. Poult. Sci. 84:1370-1375.

Roth, F. X. (2000): Pages 169-181 in XVI Curso de Especialización FEDNA: Avances in Nutrición y Alimentación Animal. Fund. Esp. Desarro. Nutr. Anim., Barcelona, Spain.

Sadeghi GH, Karimi A, PadidarJahromi SH, Azizi T and Daneshmand A (2012): Effects of Cinnamon, Thyme and Turmeric Infusionson the Performance and Immune Response in of 1to 21Day-Old Male Broilers. Brazilian Journal of Poultry Science .14 (1) 15-20.
Sevanian A, Mcleod L (1997): Formation of Biological Reactivity of Lipid Peroxidation Products. Taylor and Francis, Washington DC, pp. 47-70.

Schoene, F., Vetter, A., Hartung, H., Bergmann, H., Biertumpfel, A., Richter, G., Mueller, S. and Breitschuh, G. (2006): Effects of essential oils from fennel (Foeniculi aetheroleum) and caraway (Carvi aetheroleum) in pigs. J. Anim. Physiol. Anim. Nutr., 90: 500 510.

Snedecor, F.W. and W.G. Cochran, (1980): Statistical methods $7^{\text {th }}$ ed.Lowa State Univ. Press Ames .I.A.

Sumners,L. H. , C. M. Cox , S. Kim , J. E. Salevsky , P. B. Siegel , and R. A. Dalloul1(2012): Immunological responses to Clostridium perfringens alpha-toxin in two genetically divergent lines of chickens as influenced by major histocompatibility complex genotype. Poultry Science 91: 592598.

Tabak, M., Armon, R. and Neeman, I. (1999): Cinnamon extracts' inhibitory effect on Helicobacter pylori. J. Ethnopharmacology, 67: $269-277$. Taylor, D.J. (2001): Effects of antimicrobials and their alternatives. Br. Poult. Sci., 42 (suppl): 67-68.

Tony, M.A., M. M. Hamoud, C. A. Bailey and H. M. Hafez, (2014): Effects of coated sodium butyrate as a feed additive on zootechnical performance, immune 
status and Salmonella Enteritidis shedding after experimental infection of broiler chickens. Proceeding of Poultry Science Association meeting, Corpus Christi, Texas, USA.

Van Immerseel, F., J. De Buck, F. Pasmans, G. Huyghebaert, F. Haesebrouck, and R. Ducatelle, (2004): Clostridium perfringens in poultry: An emerging threat for animal and public health. Avian Pathol. 33:537-549.

Warrell, D. T. C., J. Firth, and E. J. Benz Jr. (2003): Oxford Textbook of Medicine. 4th ed. Oxford University Press, Oxford, UK.

Wenk, C., (2000): Recent Advances in Animal Feed Additives such as Metabolic Modifiers, Antimicrobial Agents, Probiotics, Enzymes and Highly Available
Minerals. Review. Asian-Aust. J. Anim. Sci., 13: 86-95.

Yakhkeshi S, Rahimi S GharibNaseri K (2011): The Effects of Comparison of Herbal Extracts, Antibiotic, Probioticand Organic Acid on Serum Lipids, Immune Response, GITMicrobial Population, Intestinal Morphology and Performance of Broilers. Journal of Medicinal Plants, 10: 37. Yang, M.D., M. B. RazaAsim, M. Sc., Xiaogang Jiang ,M. D. Bo Zhong, M. D. Muhammad Shahzad, PH.D. Fujun Zhang, B.Sc,and Lu .M.D. PH.D. Shemin, (2010): Nitric oxide in both bronchoalveolar lavage fluid and serum is associated with pathogenesis and severity of antigen-induced pulmonary inflammation in rats. Journal of Asthma, 47:135-14. 